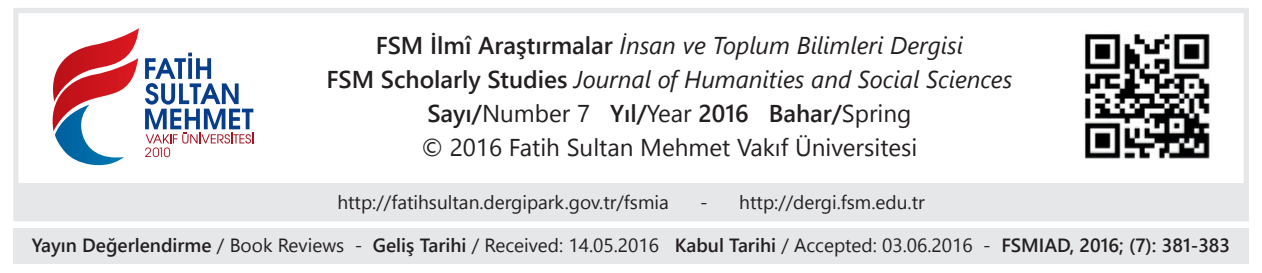

\title{
İsmail Küçükkılınç, Jön Türklük ve Kemalizm Kıskacında İttihadçlık,
} İstanbul: Ötüken Neşriyat, 2016, 9786051553276, 352 s. Ömer Şerif Turan*

Tarih kıymet hükmü demektir. Bu kıymet tarihçiler/araştırmacılar tarafından geçmişin -sesi yakın- yankısıyla doğru bir şekilde kitap sayfalarına kaydedilmek ve böylece geleceğe taşınmak zorundadır. Yakın tarihle alakalı ilgi çekici bu eser hukukçu yazar İsmail Küçükkılınç tarafından hazırlanmıştır. Kitabın yazarı ittihatçılara bakış açımızı sarsıyor ve yeniden düşünmemize vesile oluyor. Yeniden düşünmek ittihatçılar hakkında bugüne kadar vardığımız asılsız kanıları, zihinlerimizdeki ve kalbimizdeki yargısı infazları gidermeye yeterli olur mu bilemeyiz fakat yakın tarih hakkında bizi aydınlığa götüreceği su götürmez bir gerçek olarak karşımızda duruyor. Yazar kitabın hemen her sayfasında adeta kanıksadığımız üzere ittihatçıları yerden yere vurmak yerine onların yaşadıklarını ve yaşananların insani taraflarını bize akıcı ve nezih bir üslup ile aktarıyor. Yazar söz konusu tezlerini savunurken, literatürde bilinmeyen, kendisinin ortaya çıkardığ 1 bilgi ve belgeleri kullandığı iddiasında değildir. Ancak önemli bir kısmı akademik camia ve kamuoyunun ilgi ve dikkatini çekmeyen bilgi ve tanıklıkları genel olarak kaynak tenkidi de yaparak okuyucuya sunmuş ve tezlerinde bütünlüklü ve tutarlı olarak kullanmıştır.

Kitap numaralı başlıklar ile bölümler halinde adeta bir ders kitabı nizamına sahip. Her başlık örgü örgü ittihatçılar hakkında bugüne kadar öğrendiğimiz meseleleri hakiki manada su yüzüne çıkartıyor. Kavram Kargaşası ve Kafa Karışıklığı: Jön Türklük ve İttihadçılık Aynı ve Birbirinin Devamı Yapılar mıdır, Osmanlı Hürriyet Cemiyeti'nin Eseri ve Bir Makedonya Hareketi Olarak İttihadçılık, İttihadçılık ve Komitacılık, Meşrutiyet'in İlanı, 31 Mart Vak'ası, İTC Devlet İçinde Devlet miydi, Masonluk-Siyonizm, Makedonya'dan Anadolu’ya

* Yüksek lisans öğrencisi, Fatih Sultan Mehmet Vakıf Üniversitesi Sosyal Bilimler Enstitüsü Tarih Ana Bilim Dalı, İstanbul/Türkiye, omer_serif_turan@hotmail.com 
İttihadç1lı: Balkan Harbi ya da Hezimetten Milletin Kurtuluşuna, Darbe Geleneği, Halaskar Zabitan Grubu, Birinci Dünya Harbi, Teşkilat-1 Mahsusa, Ermeni Meselesi, Kara Kemal, Mustafa Kemal, Talat Paşa, Sadrazam Tevfik Paşa, Elazı ̆̆ Valisi Ali Galip, Kahya Yahya, Ali Şükrü Bey, İsmail Hakkı Tekçe, Topal Osman, Çerkez Ethem, Nazım Bey, Kazım Karabekir'e suikast Teşebbüsü ve İstiklal Harbimizin Esasları Kitabının Yakılması, Nureddin Paşa, Selamet-i Umumiye Komitesi, Milli Mücadele, Kemalizm ve sair işlenen birçok mühim mevzu satırlar arasında okuru yakın tarihe farklı bir açıdan bakmaya davet ediyor. Elbette işlenen mevzular bir kitapla sınırlandırılacak kadar kısa değil lakin yazar hem öz anlatımıyla hem de verdiği vesikalarla, dipnotlarla okunması elzem olan bilgi örgüsünü halis bir biçimde oluşturmuş.

Yazar, İttihadçı1ık ve İttihatçılar konusunda muhafazakâr mütedeyyin kesim, Kemalistler ve liberallerin düşmanca denilebilecek olumsuz bakış açılarını kaynaklara dayanarak eleştirmektedir. Yazara göre geleneksel muhafazakâr mütedeyyin çevrelerdeki İttihadçı algısı Sultan Abdülhamid odaklıdır. İttihadçılar yabancı güçlerin yönlendirmesi ile Sultan Abdülhamid'i tahttan indiren ve böylece koskoca imparatorluğu harbe sokarak batıran komitacı maceracı siyonist, mason, dönme ve dinsizler koalisyonudur. Kemalist bakış açısına göre de İttihadçılar, imparatorluğu batırmış daha sonra da Mustafa Kemal'in şahsını ortadan kaldırmaya çalışmış maceracı, hayalperest, komitacı zihniyeti temsil etmektedir. Liberal çevreler için ise İttihadçılar Türk olmayanları dışlayan onlara tehcir ve katliam dâhil her türlü şiddeti uygulamaya önceden kararlı homojen bir grup olarak görülmektedir. Kitap, İttihadçılara yönelik darbeci ve komitacı ithamlarının da gerçekle çok fazla uyuşmadığının misallerini vermektedir. Meşrutiyet devrinde ilk siyasi darbeye 1912 yılında İttihadçıların maruz kaldığı ve komitacılık ithamının da daha ziyade Rumeli' de 1908 öncesi devletin yargı yetkisini kullanamaz hale gelmesinden ötürü bazı subay ve mülki idare amirlerinin kendi işlerini kendileri görmek zorunda kalmalarından dolayı zihinlere yerleştiği eserin savunduğu önemli tezlerdendir. Birinci Dünya Harbi içinde Ermeni tehcirinin tehcirin 1ztırar hali olduğunu savunan eserde, tehcirle Balkan Harbi'nde neredeyse Avrupa topraklarının tamamını kaybeden Osmanlı Devleti'nin Doğu Anadolu'da bir Ermenistan kurulmasını önlediği kanaati paylaşılmaktadır. Filistin konusunda hassasiyeti bilinen Sultan Abdülhamid'in bölgeye Yahudi göçüne mani olacak yaptırım gücünden yoksun oluşuna işaret edilmiştir. Milli Mücadele döneminde Kâzım Karabekir Paşa'nın şahsi siyasi beklentilerle Enver Paşa aleyhine girişimleri de eserde keskin ifadelerle tenkit edilmiştir.

On dokuzuncu yüzyıl tarih çağları içerisinde belki de en uzun süren yüzyıl olma özelliğine sahiptir. İlginç fakat nitelikli bir bakış açısı ile 1789 yılı Fransız İhtilalı ile başlamış ve fakat 1914'e kadar yani Birinci Dünya Savaşı'na kadar devam etmiştir. Yüzyılı fazlasıyla aşan bu süre zarfında Osmanlı İmparatorluğu 
gücünü bir hayli yitirmiş ve adeta tepeden tırnağa kalıcı manada bir güncelleme gerçekleştirememiştir. Bu uzun yüzyılın sonlarına doğru meydana gelen siyasi ve sosyal hareketler Osmanlı İmparatorluğu'nu kurtarma çırpınışlarıdır. İttihatçılar üzerlerine düşeni yapmaya çalışarak bir nevi kurtarma çabasını üzerlerine vazife olarak görmüşlerdir. Kitap ittihatçıları haklı veya haksız görerek keskin bir çizgi çizmek ve taraf olmak yerine, bugünden geçmişe doğru bakarken; yanlış bildiğimiz doğruların veya doğru bildiğimiz yanlışların altını çizmeyi yeğ tutmuştur. Bu manada yazar tebrik ve takdire şayan bir emek ortaya koymuştur.

Kitap alışılagelmiş bir tarih kitabı olmaktan ziyade, Osmanlı'nın son dönemlerinde vuku bulmuş hadiseleri izah etme gayreti içinde muhtelif araştırma yazılarının bir sonucu olarak derlenmiştir. Bilhassa on dokuzuncu yüzyılın sonu ve yirminci yüzyılın başı ile ilgili müstakil çalışmalar yapmayı hedefleyen bilim insanlarının istifade edebileceği bilgi donanımına sahiptir. Öte yandan modernleşme hareketlerinin coğrafi olarak (Anadolu dışındaki topraklar) Osmanlı üzerindeki siyasi etkilerini de ele alan yazar, bu siyasi etkilerin cumhuriyetin ilanı ile birlikte nasıl bir alg1 çarpıklığına uğratıldığını da net bir şekilde ifade etmiştir. Her toplum devleti ile birlikte ayakta durur. Toplumu bu dünya içerisinde huzurlu ve sağlıklı bir yaşam içerisine ulaştıracak olan kendi dinamikleridir. Osmanlı yüzyıllar boyunca tebaasına sağladığı adaleti, huzuru ve barışı son yüzyılında kaybetmiş ve devlet kendi bünyesinden neşvünema bulan bir yapı içerisinde teşekkül etmiştir. İttihatçılar toplumun her kademesinde muhtelif görevlere talip olmuşlar ve bu görevleri icra ederken hatalar da yapmışlardır. Yazar bu kitap ile okuyucusuna vicdanlardaki yarg1 terazisini doğru tutmayı tavsiye eder bir söylemde bulunmaktadır. Zihinlerdeki üstü tozlu katı kapaklı algıları güncellemenin zamanının geldiğini söylemektedir.

Cumhuriyetin kuruluşundan bugüne kadar Türk toplumunun yaşadığı her hadisenin kaynağı ittihatçıların dönemine, Sultan II. Abdülhamit'in dönemine kadar götürülebilir. Bu sadece menfi anlamda değil müspet anlamda da böyledir. Bundan bir asır önce bu topraklarda yaşayan insanlar kendi sorunları ile hemhal olup dertlenip istikbalin yani bugünün refahı için çeşitli çabalar ortaya koymuşlardır. Bu çabalar yanlış tarih yazımları ve anlatımları ile karalanamaz. Elbette bundan yüzyıl öncesinde yaşayan toplum içerisinde meydana gelen dinamikler, ittihatçıları çeşitli hatalara da sürüklemiş̧ir. Lakin mühim olan gidilen yol kadar varılacak gayenin de ne olduğu hikmetidir. Yazar tarih alanında önemli bir çalışma ortaya koymuştur. İttihatçılık ve ittihatçılar adına birçok meseleyi, bir nevi o dönemde yaşanan serencama ait fotoğrafları önemli başlıklar altında kaleme almıştır. Yazar kaynak seçimini ve kullanımını özenli bir şekilde yapmıştır. $\mathrm{Bu}$ kitabın tarih araştırmaları sahasında, özgün tespitleriyle, muhtelif ilmi-siyasi koordinatlardaki okuyuculara farklı bakış açılarının ipuçlarını sunacak bir potansiyele sahip olduğu gün geçtikçe daha iyi anlaşılacaktır. 